\title{
The Influence of Mass Tourism and Hygroscopic Inertia in Relative Humidity Fluctuations of Museums Located in Historical Buildings
}

\author{
Cláudia Ferreira®[1]; Vasco Peixoto de Freitas ${ }^{\circledR[1]}$; João Delgado®[1] \\ ${ }^{[1]}$ University of Porto, Faculty of Engineering, Civil Engineering Department, \\ Construct - Institute of R\&D in Structures and Construction, Portugal
}

\begin{abstract}
The preservation of artefacts in museum collections is profoundly affected by fluctuations in temperature and relative humidity. This work presents the results of an experimental laboratorial study, conducted in a flow chamber to demonstrate the enormous potential of hygroscopic materials in stabilizing interior relative humidity. In order to assess the risk of mass tourism and hygroscopic inertia of finishing materials, associated with the hygrothermal behavior of museums, an analysis of several numerical scenarios, with a different number of visitors per hour, and finishing materials, in order to quantify the risks associated with the fluctuations of relative humidity. The results of sensitivity studies performed are presented for the case of a museum in Porto.
\end{abstract}

\section{Keywords}

Mass Tourism, Hygroscopic Inertia, Relative Humidity, Museums, Collections Preservation.

\section{Introduction}

One of the main functions of museums all over the world is the conservation of artefact collections. This complex work includes, among other things, the control of the interior climate conditions (i.e., temperature, $\mathrm{T}$, and particularly relative humidity, $\mathrm{RH}$ ) inside the museum buildings (MacIntyre, 1934; Rawlins, 1942; Thomson, 1986).

In the rehabilitation of museums in ancient buildings, active systems for interior climate control have frequently been favored over passive ones. However, in countries with a temperate climate, such as Portugal, hygroscopic inertia combined with adequate ventilation may help control relative humidity fluctuations in ancient buildings without the need for complex active systems.

Hygroscopic inertia refers to the capacity of a room to store excess moisture from the air and restore it to the atmosphere when the relative air humidity is low. The finishings and the stored materials used in the rooms are one of the main factors responsible for the storage and restitution of humidity. Hygroscopic inertia may be assessed over short periods of time (short-cycle hygroscopic inertia of rooms) and for longer periods (long-cycle hygroscopic inertia of rooms).

In the Laboratory of Building Physics, at Faculty of Engineering of University of Porto (FEUP), important research has been carried out in the domain of daily (i.e. short-cycle) hygroscopic inertia in order to quantify the performance of render materials (through parameters that indicate their water vapor adsorption and restitution capacity), find models with which to 
The Influence of Mass Tourism and Hygroscopic Inertia in Relative Humidity Fluctuations of Museums Located in Historical Buildings

Cláudia Ferreira; Vasco Peixoto de Freitas \& João Delgado

assess the influence of daily hygroscopic inertia upon peaks of relative humidity and develop experimental studies to measure the phenomenon and validate the models (Freitas \& Abrantes, 1988; Ramos, 2007; Delgado, Ramos, \& Freitas, 2009; Ramos \& Freitas, 2009).

It is crucial the control of relative humidity and temperature fluctuations to preserve the museum's collections. Today, there are advanced hygrothermal simulation tools to predict the climate inside, taking into account the geometry of the building, the finishing materials, the ventilation, and the occupancy.

In the last years, LFC-FEUP research group has validated the hygrothermal numerical simulation model (Wufi-Plus), in different museums, by comparing numerical and experimental results of interior climate, using for this purpose several sensors.

The mass tourism has led to an exponential increase in museums occupancy with serious consequences on indoor temperature and relative humidity change that may put at risk the preservation of the exhibited collections.

In order to assess the hygroscopic inertia of finishing materials associated with the hygrothermal behavior of museums, an advanced hygrothermal numerical simulation model was used to evaluate those risks, for a generic museum room (model) located in a historical building of different Portuguese climatic zones.

\section{Laboratory Experiments}

\section{RHS Parameter}

Relative humidity stabilization parameter (RHS) consists of the sum over a year of the absolute differences between the 90 days mean seasonal relative humidity and the relative humidity in each hour (Ferreira, Freitas, \& Delgado, 2019). The parameter is critical, fundamentally, for organic materials, but should be in mind that other important parameters should be considered.

$$
R H S=\prod_{i=1}^{8760}\left|\overline{R H}_{i, \text { seasonal }} \square R H_{i}\right|
$$

This parameter allows quantifying the greater or lesser relative humidity stabilization over a year. To estimate the seasonal change in the climate, a running average $\left(\overline{R H}_{i, \text { seasonal,90d }}\right.$ ) is calculated for each hour and consists of the arithmetic average of the hourly values of 45 days or 1080 hours before, and 45 days or 1080 hours after (see Eq. (2)). This period is centered, which means for each value looking back one month and a half and looking forward one month and a half.

$\overline{R H}_{i, \text { seasonal }, 90 d}=\frac{1}{2161} \sum_{a=i-1080}^{i+1080} R H_{a}$ 
The Influence of Mass Tourism and Hygroscopic Inertia in Relative Humidity Fluctuations of Museums Located in Historical Buildings

Cláudia Ferreira; Vasco Peixoto de Freitas \& João Delgado

\section{Materials and Methods}

A coating material, normally, used in the rehabilitation of historical buildings, was select to evaluate the hygroscopic behavior, as well as the contribution to the control of indoor relative humidity. The material selected, with a thickness of $15 \mathrm{~mm}$, was a $1.5 \mathrm{~mm}$ diameter wood fibers panels agglomerated with white cement (Material B).

From the experimental results reported in Table 1 it is possible to observe that Material $B$ is very permeable to water vapor, and the water vapor permeability, $\delta_{p}$, is dependent on the prevailing relative humidity and generally changes rapidly at high $\mathrm{RH}$. This material presents a greater amount of adsorbed water vapor (MBV) for the relative humidity range of $33 \%$ to $75 \%$, with $94.7 \mathrm{~g} / \mathrm{m}^{2}\left(2.25 \mathrm{~g} / \mathrm{m}^{2} \% \mathrm{RH}\right)$. Nordtest report (Rode et al., 2005) classified the capacity of materials to buffer moisture of indoor environment, according to their MBV obtained from MBV test with a range of $33 \%-75 \% \mathrm{RH}$. As so, Material $\mathrm{B}$ is classified as excellent material (MBV>2 $\mathrm{g} / \mathrm{m}^{2} \% \mathrm{RH}$ ) to buffer moisture. Finally, these experiments allowed concluding that Material B presents a hygroscopic capacity of $0.07 \mathrm{~kg} / \mathrm{m}^{2}$ (calculated by the product of equilibrium moisture content with material density and thickness at different $\mathrm{RH}$ 's) for a relative humidity variation between $50 \%$ and $70 \%$.

\section{Properties}

Density, $r\left(\mathrm{~kg} / \mathrm{m}^{3}\right)$

Porosity, e (-)

Heat capacity, $c_{\mathrm{p}}(\mathrm{J} / \mathrm{kgK})$

Thermal conductivity, I W/mK)

Water vapor permeability, $\delta_{\mathrm{p}}(\mathrm{kg} / \mathrm{msPa})$

Water vapor diffusion resistance factor, $\mu(-)$

Equivalent air layer thickness, $s_{d}(m)$

Moisture Buffer Value, MBV $\left(\mathrm{g} / \mathrm{m}^{2} . \% \mathrm{RH}\right)$

Hygroscopic sorption curve $(\mu, \varphi)$
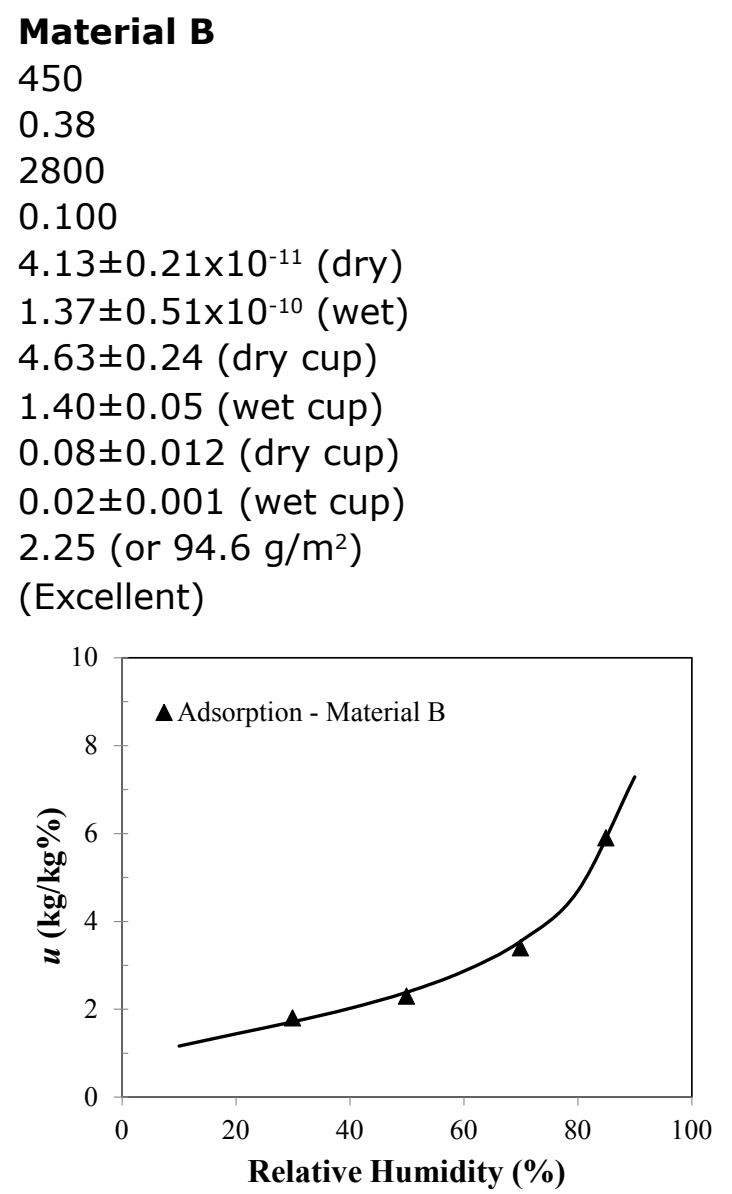

Table 1 - Hygroscopic properties of the selected material. 
The Influence of Mass Tourism and Hygroscopic Inertia in Relative Humidity Fluctuations of Museums Located in Historical Buildings

Cláudia Ferreira; Vasco Peixoto de Freitas \& João Delgado

The flux chamber (see Figure 1), with dimensions $1500 \times 524 \times 584 \mathrm{~mm}^{3}$, was installed in a climatic chamber with controlled temperature ( $\mathrm{T}$ in the range $15^{\circ} \mathrm{C}-35^{\circ} \mathrm{C}$ ) and relative humidity ( $\mathrm{RH}$ in the range $30 \%-90 \%$ ). The temperature and relative humidity could be controlled by fixing values or using programmable cycles including the variation of one or both parameters. The ventilation system presents two points, inside the flux chamber, to extract the air and an inlet on top allows for the air to get in and at the same time prevents pressure differences. The flux chamber inlet air comes directly from the climatic chamber and its characteristics are known, whereby infiltration through the openings does not affect the overall balances of heat, air, and moisture. The air flux value is controlled by flow meters with a range of air exchange rate (ach) of $0.26-17 \mathrm{~h}^{-1}$.


Figure 1 - Sketch of the flux chamber.


Figure 2 - Flux chamber exterior climate (summer and winter cycles).

\begin{tabular}{|l|c|c|l|}
\hline \multirow{2}{*}{ Ref. } & Climatic chamber & \multicolumn{2}{|c|}{ Flux chamber } \\
\cline { 2 - 4 } & Cycle & ach $\mathbf{( h}^{-\mathbf{1}}$ ) & Hygroscopic material \\
\hline Conf. 2.1 & Summer & 0.26 & -- \\
\hline Conf. 2.3 & Summer & 0.65 & -- \\
\hline Conf. 2.5 & Summer & 0.26 & $0.75 \mathrm{~m}^{2}$ of Material B \\
\hline Conf. 2.7 & Summer & 0.65 & $0.75 \mathrm{~m}^{2}$ of Material B \\
\hline Conf. 2.2 & Winter & 0.26 & -- \\
\hline Conf. 2.4 & Winter & 0.65 & -- \\
\hline Conf. 2.6 & Winter & 0.26 & $0.75 \mathrm{~m}^{2}$ of Material B \\
\hline
\end{tabular}


The Influence of Mass Tourism and Hygroscopic Inertia in Relative Humidity Fluctuations of Museums Located in Historical Buildings

Cláudia Ferreira; Vasco Peixoto de Freitas \& João Delgado

\begin{tabular}{|l|l|l|l|}
\hline Conf. 2.8 & Winter & 0.65 & $0.75 \mathrm{~m}^{2}$ of Material B \\
\hline
\end{tabular}

Table 2 - Configurations tested in the flux chamber.

The flux chamber was subject to a different cycle of exterior climate generated by the surrounding climatic chamber, and it was tested with an hourly air change rate of $0.26 \mathrm{~h}^{-1}$ and $0.65 \mathrm{~h}^{-1}$ (values selected in accordance with the flux chamber limitations), and an area of $0.75 \mathrm{~m}^{2}$ of hygroscopic coating material. The exterior climate was defined based on the average climatic conditions inside a museum located in the city of Porto, and consisted of the definition of summer and winter cycles, as sketched in Figure 2. The tested configurations analyzed in the flux chamber are described in Table 2.

\section{Experimental Results}

In Figure 3 and Table 3 are presented the results of the temperature and relative humidity obtained for the tested configurations, with different air change rate, and for the summer cycle and winter cycle. The main conclusions were:

(1) The test results carried out in the flux chamber demonstrate that the introduction of the hygroscopic coating material (Material B) influences the fluctuation of the relative humidity inside the flux chamber;

(2) This influence is visible when comparing the variation between the maximum and minimum relative humidity - $\Delta R H$ of Conf. 2.1 and Conf. 2.5 or Conf. 2.3 and Conf. 2.7 (summer cycle); and Conf. 2.2 and Conf. 2.6 or Conf. 2.4 and Conf. 2.8 (winter cycle), with different air change rates.
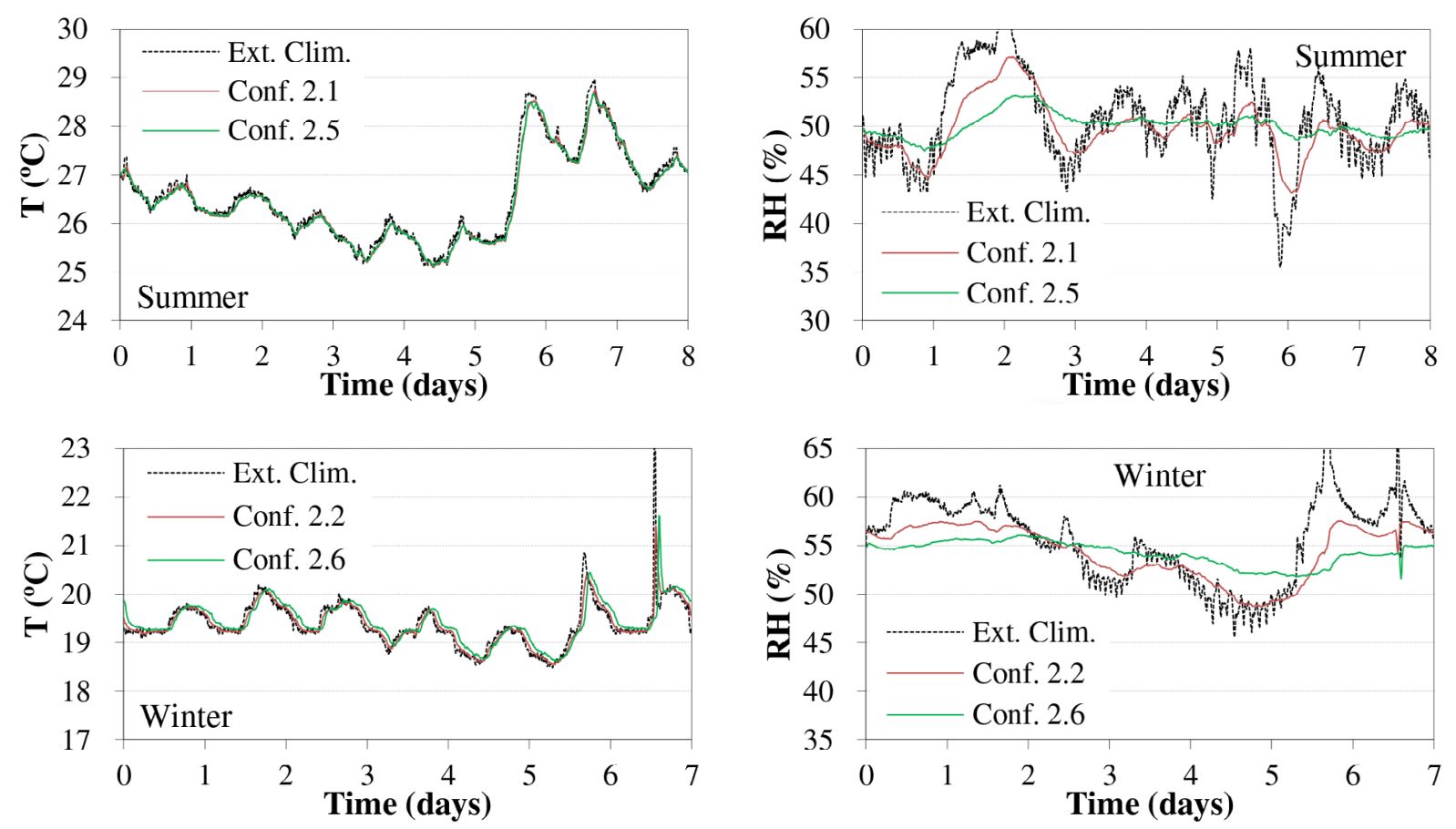
The Influence of Mass Tourism and Hygroscopic Inertia in Relative Humidity Fluctuations

of Museums Located in Historical Buildings

Cláudia Ferreira; Vasco Peixoto de Freitas \& João Delgado

Figure 3 - Temperature and relative humidity variation observed, with ach $=0.26 \mathrm{~h}^{-1}$, in: (a) Summer cycle and (b) Winter cycle.

Hygroscopic capacity $\left(C_{\text {apHyg }}\right)$ was calculated for the different configurations tested using Equation (3), and the results obtained described in Table 3:

$C_{\text {apHyg }}\left(g / \mathrm{m}^{3} \% \mathrm{RH}\right)=\frac{\sum_{i} M B V_{i} \times S_{i}}{V}$

where $M B V_{\mathrm{i}}$ is the Moisture Buffer Value of the finishing material $\left[\mathrm{g} / \mathrm{m}^{2} \% \mathrm{HR}\right], S_{\mathrm{i}}$ is the surface area $\left[\mathrm{m}^{2}\right]$ and $V$ is the volume $\left[\mathrm{m}^{3}\right]$ of the flux chamber.

\begin{tabular}{|c|c|c|c|c|c|c|c|c|c|c|}
\hline $\begin{array}{l}\text { Relative } \\
\text { humidity }\end{array}$ & $\begin{array}{c}\text { Ext. } \\
\text { Clim. }\end{array}$ & $\begin{array}{c}2.1 \\
0.26 h^{-1}\end{array}$ & $\begin{array}{c}2.3 \\
0.65 h^{-1}\end{array}$ & $\begin{array}{c}2.5 \\
0.26 h^{-1}\end{array}$ & $\begin{array}{c}2.7 \\
0.65 h^{-1}\end{array}$ & $\begin{array}{l}\text { Ext. } \\
\text { Clim. }\end{array}$ & $\begin{array}{c}2.2 \\
0.26 h^{-1}\end{array}$ & $\begin{array}{c}2.4 \\
0.65 \mathrm{~h}^{-1}\end{array}$ & $\begin{array}{c}2.6 \\
0.26 h^{-1}\end{array}$ & $\begin{array}{c}2.8 \\
0.65 \mathrm{~h}^{-1}\end{array}$ \\
\hline$C_{\text {apHyq }}\left(\mathrm{g} / \mathrm{m}^{3} \% \mathrm{RH}\right)$ & -- & \multicolumn{2}{|c|}{0.00} & \multicolumn{2}{|c|}{3.68} & -- & \multicolumn{2}{|c|}{0.00} & \multicolumn{2}{|c|}{3.68} \\
\hline Maximum & 62.34 & 57.16 & 58.91 & 53.16 & 54.45 & 69.93 & 57.51 & 60.61 & 56.05 & 57.44 \\
\hline Minimum & 35.48 & 43.17 & 40.66 & 47.47 & 47.22 & 45.06 & 48.71 & 48.05 & 51.58 & 51.25 \\
\hline Average & 50.76 & 49.70 & 49.84 & 50.08 & 50.26 & 55.66 & 54.37 & 54.69 & 54.24 & 54.97 \\
\hline St. Dev. & 4.60 & 2.816 & 3.547 & 1.21 & 1.596 & 4.253 & 2.765 & 3.359 & 1.209 & 1.846 \\
\hline$\Delta \mathrm{RH}$ & 26.86 & 13.99 & 18.25 & 5.69 & 7.23 & 24.87 & 8.79 & 12.56 & 4.47 & 6.19 \\
\hline RHS & -- & 21286 & 26051 & 10513 & 14166 & -- & 21286 & 26051 & 10513 & 14166 \\
\hline
\end{tabular}

Table 3 - Hygroscopic capacity, maximum, minimum and average values of relative humidity obtained in the flux chamber, for summer and winter cycle, with different air change rate.

\section{Numerical Analysis}

The main objective is to evaluate the performance of the museum rooms with different hygroscopic finishing materials and ventilation rates. The boundary conditions associated with the outside and inside climates and the constitution of the building's envelope are required. Thus, data concerning the building model (see Figure 4), the geometry of the envelope (materials and their properties), exterior climate ventilation and internal gains (number of visitors) were introduced into the model. 
The Influence of Mass Tourism and Hygroscopic Inertia in Relative Humidity Fluctuations of Museums Located in Historical Buildings

Cláudia Ferreira; Vasco Peixoto de Freitas \& João Delgado

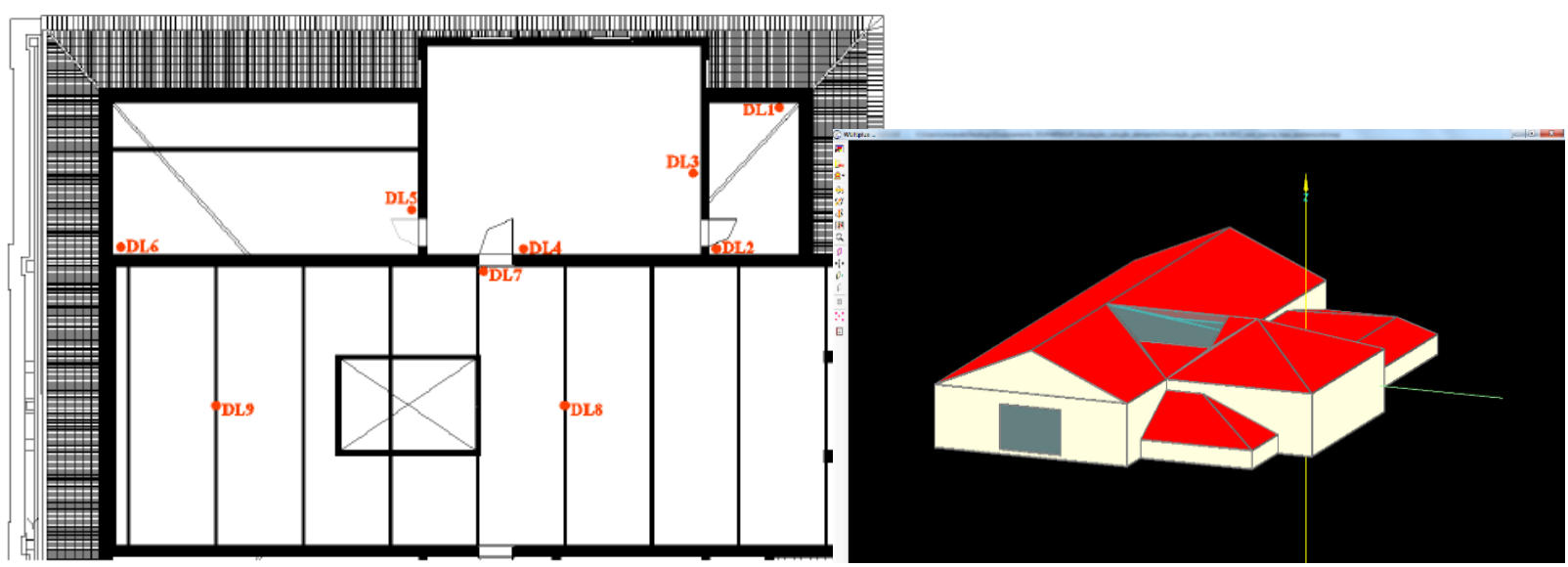

Figure 4 - Museum room plant and the model building used in this study.

In accordance with the experimental results, a preliminary numerical study was conducted using Wufi-Plus hygrothermal model of advanced numerical simulation (IBP, 2010). The main objective is to evaluate the performance of the museum rooms with different hygroscopic finishing materials, ventilation rates, and occupancy, specifically in terms of temperature and relative humidity fluctuations. For this purpose, Table 4 presents several variables of the outdoor climate tested according to the specific weather file used. In this preliminary analysis, only Porto city was considered.

\begin{tabular}{|c|c|c|c|c|c|c|c|}
\hline \multirow{2}{*}{ District } & \multirow{2}{*}{$\begin{array}{l}\text { Climatic } \\
\text { zone }\end{array}$} & \multicolumn{3}{|c|}{ Temperature $\left[{ }^{\circ} \mathrm{C}\right]$} & \multicolumn{3}{|c|}{ Relative Humidity [\%] } \\
\hline & & Mean & Maximum & Min & Mean & Maximum & Mini \\
\hline & $\mathrm{I} 2-\mathrm{V} 1$ & 15.2 & 38.4 & 0.3 & 73.3 & 99.0 & 9.40 \\
\hline
\end{tabular}

Table 4 - External climate data considering the climatic file used in the simulation (annual values).

\begin{tabular}{|l|l|l|}
\hline Component & Description & Finishing material \\
\hline Outer walls & Granite walls with ETICS & Lime mortar with painting \\
\hline Inner walls & $\begin{array}{l}\text { Granite walls with lime-based ren- } \\
\text { dering on both surfaces }\end{array}$ & Lime mortar with painting \\
\hline Roof & $\begin{array}{l}\text { Ceiling in gypsum board plus thermal } \\
\text { insulation }\end{array}$ & $\begin{array}{l}\text { Gypsum board with } \\
\text { painting }\end{array}$ \\
\hline Floor & Reinforced concrete slab & Old Oak without varnish \\
\hline
\end{tabular}

Table 5 - Constitution of each component and respective finishing material (base scenario).

\begin{tabular}{|l|l|l|l|l|}
\hline Properties & Lime mortar & $\begin{array}{l}\text { Gypsum } \\
\text { board }\end{array}$ & Old Oak & Material B \\
\hline
\end{tabular}


The Influence of Mass Tourism and Hygroscopic Inertia in Relative Humidity Fluctuations of Museums Located in Historical Buildings

Cláudia Ferreira; Vasco Peixoto de Freitas \& João Delgado

\begin{tabular}{|c|c|c|c|c|c|}
\hline Bulk density $\left[\mathrm{kg} / \mathrm{m}^{3}\right]$ & \multicolumn{2}{|c|}{1785} & 850 & 740 & \multirow{7}{*}{ See } \\
\hline Porosity [-] & 0.28 & & 0.65 & 0.35 & \\
\hline Specific heat capacity $[\mathrm{J} / \mathrm{kgK}]$ & 850 & & 850 & 1600 & \\
\hline Thermal conductivity $[\mathrm{W} / \mathrm{mK}]$ & 0.70 & & 0.20 & 0.1522 & \\
\hline $\begin{array}{l}\text { Water vapor diffusion resistance } \\
\text { factor [-] }\end{array}$ & 15 & & 8.3 & 223 & \\
\hline \multirow[t]{2}{*}{ Hygroscopic sorption curve } & \multicolumn{4}{|c|}{\begin{tabular}{|lll}
50 \\
10
\end{tabular}} & \\
\hline & & $x^{2}$ & & $\sin$ & \\
\hline
\end{tabular}

Table 6 - Main properties of the hygroscopic finishing materials used in numerical simulation.

As regards the envelope, Table 5 gives a brief description of the constitution of each component and the material used in the final rendering. The properties of these materials were not determined experimentally. Instead, the database of the program Wufi-Pus was used, which contained selected materials with similar properties to the finishing materials existing in the museum. Table 6 shows the properties of the finishing materials used for the interior layer with higher relevance for the hygrothermal calculation. The area of the hygroscopic finishing material (Material B) used was $168.4 \mathrm{~m}^{2}$.

Ventilation rates $\left(0.24 \mathrm{~h}^{-1}\right.$ and $0.98 \mathrm{~h}^{-1}$, typical values of the museum room analyzed) were specified as well as internal gains resultant from lighting, $9 \mathrm{~W} / \mathrm{m}^{2}$ during opening hours (from 10:00 to 18:00) and the only day closed for visitors was considered to be Monday) and $2 \mathrm{~W} / \mathrm{m}^{2}$ selected for the remaining period. Regarding occupancy, different numbers were chosen (5, 10 and 20 visitors per hour), and considering that each visit has a duration of 20 min and a typical year with 308 days of being open to the public, it results in a range of visitors annually between 36960 and 147840 .

Several parameters were used to obtain the internal gains, namely, a metabolic rate of 1.28 met and a heat gain of $134 \mathrm{~W}$, in which $60 \%$ is sensible heat and $40 \%$ is latent heat. Sensible heat is directly related to temperature ( $50 \%$ radiant and $50 \%$ convective). Considering the ventilation flow of $0.26 \mathrm{~h}^{-1}$ and taking into account that each visitor releases $70 \mathrm{~g} / \mathrm{h}$ of water vapor in the duration of 8 h (BS 5250, 2011), the internal water vapor gain is given by:

Inter.Gain $=\frac{n \cdot w \cdot h}{\text { ach.V.24 }}$ 
The Influence of Mass Tourism and Hygroscopic Inertia in Relative Humidity Fluctuations of Museums Located in Historical Buildings

Cláudia Ferreira; Vasco Peixoto de Freitas \& João Delgado

where $n$ is the number of visitors, $\omega$ the water vapor produced by each visitor $(70 \mathrm{~g} / \mathrm{h}), h$ the number of hours of the visit $(8 \mathrm{~h})$, ach the ventilation rate $\left(0.26 \mathrm{~h}^{-1}\right), v$ the room volume $\left(206 \mathrm{~m}^{3}\right)$ and 24 the factor used to obtain the mean hygrometry.

\section{Results and Discussion}

Tables 7 and 8 present the indoor climate characterization, specifically concerning temperature and relative humidity, in order to better perceive the implications associated with the different variables analyzed in performed simulations.

Figures 5 and 6 show, as an example for Porto, the seasonal temperature, and relative humidity obtained for the different scenarios studied. It is possible to observe an increase of temperature and $\mathrm{RH}$ with the number of visitors, however, the increase of $\mathrm{RH}$ is significantly lesser when the museum room used hygroscopic materials, namely with an ach $=0.24 \mathrm{~h}^{-1}$. More in detail, the results show:

(1) An increase of the average temperature and relative humidity with the number of visitors per hour, for an $a c h=0.24 \mathrm{~h}^{-1}$, however, for an $a c h=0.98 \mathrm{~h}^{-1}$, the average temperature increases, and the $R H$ decreases;

(2) When the ach value is $0.24 \mathrm{~h}^{-1}$ and buffering material $B$ is used on the walls and ceilings, the value of parameter RHS drops, in average, by $27 \%$ compared to when the original materials are used;

(3) When the ach value is $0.98 \mathrm{~h}^{-1}$ and buffering material $B$ is used the value of parameter RHS reduces, in average, by $22 \%$ compared to when the original materials are used;

(4) When the ach value is $0.24 \mathrm{~h}^{-1}$ and buffering material $B$ is used on the walls and ceilings, the difference between the maximum and minimum relative humidity ranged between $28.4 \%$ and $40.0 \%$ compared to the range between $38.1 \%$ and $53.3 \%$.

When the ach value is $0.98 \mathrm{~h}^{-1}$ and buffering material $\mathrm{B}$ is used the difference between the maximum and minimum $\mathrm{RH}$ ranged between $45.8 \%$ and $65.3 \%$ compared to the range between $53.8 \%$ and $71.9 \%$.

\begin{tabular}{|c|c|c|c|c|c|c|c|c|c|}
\hline \multirow{2}{*}{\multicolumn{2}{|c|}{$\begin{array}{c}\text { Variables / No Visitors } \\
\text { per hour } \\
0\end{array}$}} & \multicolumn{4}{|c|}{ Base scenario } & \multicolumn{4}{|c|}{ Base scenario + Mat. B } \\
\hline & & 5 & 10 & 20 & $\mathbf{0}$ & 5 & 10 & 20 & \\
\hline \multirow{2}{*}{ Min } & $\mathbf{T}\left({ }^{\circ} \mathbf{C}\right)$ & 10.3 & 11.3 & 12.3 & 14.2 & 10.7 & 12.1 & 13.3 & 15.8 \\
\hline & RH (\%) & 33.7 & 40.0 & 45.0 & 50.6 & 38.3 & 45.8 & 49.7 & 54.5 \\
\hline \multirow{2}{*}{ Max } & $\mathbf{T}\left({ }^{\circ} \mathrm{C}\right)$ & 25.2 & 27.1 & 28.9 & 32.2 & 25.8 & 28.2 & 30.6 & 35.0 \\
\hline & RH (\%) & 85.3 & 93.3 & 95.9 & 99.0 & 76.6 & 81.7 & 86.1 & 91.4 \\
\hline \multirow{2}{*}{ Average } & $\mathbf{T}\left({ }^{\circ} \mathrm{C}\right)$ & 17.7 & 19.0 & 20.2 & 22.6 & 18.3 & 20.1 & 21.7 & 24.8 \\
\hline & RH (\%) & 62.0 & 69.0 & 74.8 & 83.3 & 59.7 & 64.7 & 68.5 & 72.5 \\
\hline \multirow{2}{*}{ St. Dev. } & $\mathbf{T}\left({ }^{\circ} \mathbf{C}\right)$ & 3.9 & 3.9 & 4.0 & 4.0 & 3.9 & 3.9 & 4.0 & 4.1 \\
\hline & RH (\%) & 9.1 & 8.6 & 8.9 & 9.5 & 6.6 & 6.0 & 6.4 & 7.1 \\
\hline
\end{tabular}

Table 7 - Temperature and relative humidity results for Porto with different visitors per hour and $a c h=0.24 \mathrm{~h}^{-1}$. 
The Influence of Mass Tourism and Hygroscopic Inertia in Relative Humidity Fluctuations of Museums Located in Historical Buildings

Cláudia Ferreira; Vasco Peixoto de Freitas \& João Delgado
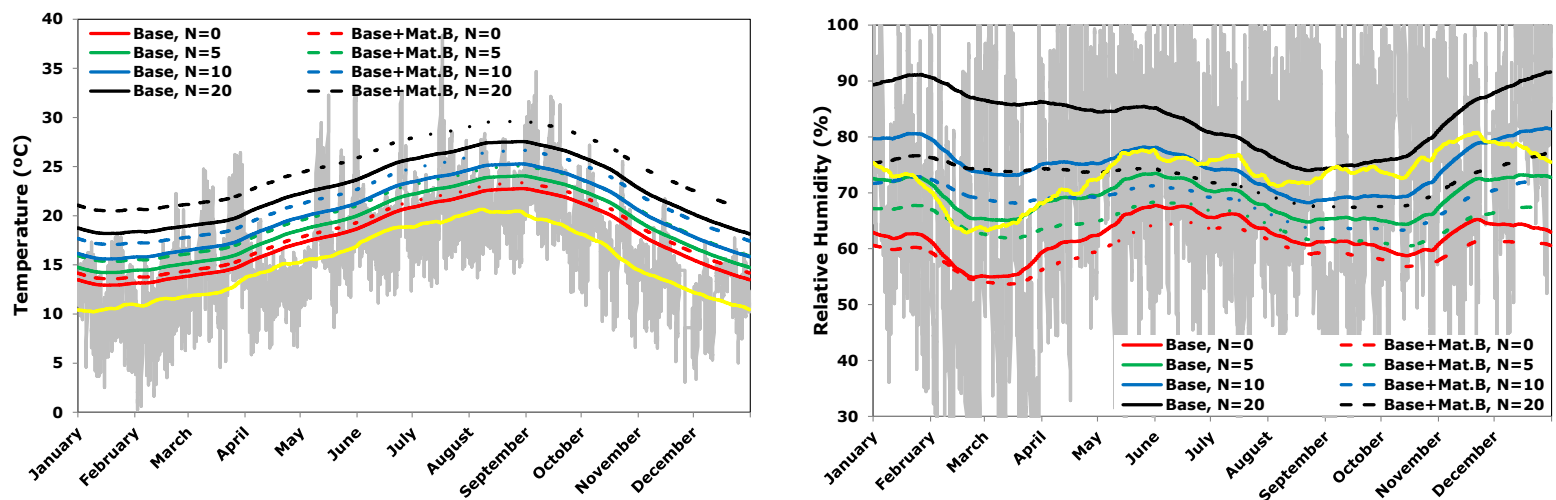

Figure 5. Numerical results for Porto, with and without buffering materials, different number of visitors per hour, and $a c h=0.24 \mathrm{~h}^{-1}$ (seasonal exterior T and RH marked as a yellow line).

\begin{tabular}{|c|c|c|c|c|c|c|c|c|c|}
\hline \multirow{2}{*}{\multicolumn{2}{|c|}{$\begin{array}{c}\text { Variables / No } \\
\text { Visitors per hour } \\
0\end{array}$}} & \multicolumn{4}{|c|}{ Base scenario } & \multicolumn{4}{|c|}{ Base scenario + Mat. B } \\
\hline & & \multirow{2}{*}{$\begin{array}{c}5 \\
8.8\end{array}$} & \multirow{2}{*}{$\begin{array}{c}10 \\
9.6\end{array}$} & \multirow{2}{*}{$\begin{array}{c}20 \\
10.4\end{array}$} & \multirow{2}{*}{$\begin{array}{c}\mathbf{0} \\
11.8\end{array}$} & \multirow{2}{*}{$\begin{array}{c}5 \\
8.6\end{array}$} & \multirow{2}{*}{$\begin{array}{c}10 \\
9.4\end{array}$} & \multirow{2}{*}{$\begin{array}{c}20 \\
10.3\end{array}$} & \multirow[b]{2}{*}{12.0} \\
\hline Min & $\mathbf{T}\left({ }^{\circ} \mathrm{C}\right)$ & & & & & & & & \\
\hline गता & RH (\%) & 23.8 & 27.2 & 26.7 & 25.8 & 25.9 & 29.2 & 28.8 & 27.2 \\
\hline \multirow{2}{*}{ Max } & $\mathbf{T}\left({ }^{\circ} \mathrm{C}\right)$ & 25.5 & 26.9 & 28.2 & 31.0 & 26.0 & 27.8 & 29.5 & 33.0 \\
\hline & RH (\%) & 95.6 & 95.6 & 95.5 & 95.0 & 91.2 & 89.4 & 87.7 & 84.7 \\
\hline \multirow{2}{*}{ Average } & $\mathrm{T}\left({ }^{\circ} \mathrm{C}\right)$ & 16.9 & 17.9 & 18.8 & 20.5 & 17.2 & 18.3 & 19.4 & 21.6 \\
\hline & RH (\%) & 64.9 & 64.3 & 63.6 & 62.5 & 63.7 & 62.5 & 61.2 & 58.5 \\
\hline \multirow{2}{*}{ St. Dev. } & $\mathbf{T}\left({ }^{\circ} \mathrm{C}\right)$ & 4.0 & 4.1 & 4.1 & 4.2 & 4.0 & 4.1 & 4.2 & 4.4 \\
\hline & RH (\%) & 12.5 & 11.8 & 11.5 & 11.4 & 10.6 & 9.9 & 9.4 & 9.0 \\
\hline
\end{tabular}

Table 8 - Temperature and relative humidity results for Porto with different visitors per hour and $a c h=0.98 \mathrm{~h}^{-1}$.


Figure 6 - Numerical results for Porto, with and without buffering materials, different number of visitors per hour, and $a c h=0.98 \mathrm{~h}^{-1}$ (seasonal exterior T and RH marked as a yellow line).

\section{Conclusions}

This work presents a study of the influence of hygroscopic materials in stabilizing the relative humidity when ventilation flows are reduced.

When this particular buffering material was analyzed numerically, as part of the walls and ceiling of the museum room, the difference between the maximum and minimum interior 
The Influence of Mass Tourism and Hygroscopic Inertia in Relative Humidity Fluctuations of Museums Located in Historical Buildings

Cláudia Ferreira; Vasco Peixoto de Freitas \& João Delgado

relative humidity decreases in more than $10 \%$, for an ach $=0.24 \mathrm{~h}^{-1}$. These results show that it is possible to use passive technique for controlling/mitigating relative humidity in storage rooms, inside museums, when ventilation flows are reduced.

\section{References}

BS 5250 (2011). Code of practice for control of condensation in buildings. British Standards Institution. Delgado, J. M. P. Q., Ramos, N. M. M., \& Freitas, V. P. (2009). Can moisture buffer performance be estimated from sorption kinetics? Journal of Building Physics, 29(4), 281-299.

Ferreira, C., Freitas, V. P., \& Delgado, J. M. P. Q. (2019). Hygroscopic Materials Influence in the Fluctuation of Relative Humidity in Museums Located in Historical Buildings. Studies in Conservation (online). https://doi.org/10.1080/00393630.2019.1638666.

Freitas, V. P., \& Abrantes V. (1988). Étude expérimentale de I'humidité de I'air dans l'intérieur dês bâtiments. Influence du comportement hygroscopique des matériaux. In Proceedings of Healthy Buildings'88, CIB, Volume 2 (pp. 201-209).

IBP-Fraunhofer-Institut für Bauphysik (2010). Fundamentals of WUFI-Plus. In Seminar: Simultaneous Calculation of Transient Hygrothermal Conditions of Indoor Spaces and Building Envelopes. Holzerkirchen, Germany.

MacIntyre, J. (1934). Some problems connected with atmospheric humidity. Some notes on atmospheric humidity in relation to works of art. Courtauld Institute of Art, London, UK, 7-16.

Ramos, N. M. M., \& Freitas, V. P. (2009). An experimental device for the measurement of hygroscopic inertia influence on RH variation. Journal of Building Physics, 33(2), 157-170.

Ramos, N. M. M. (2007). The importance of hygroscopic inertia in the hygrothermal behaviour of buildings (Doctoral dissertion). Faculdade de Engenharia da Universidade do Porto, Portugal.

Rawlins, F. I. G. (1942). The control of temperature and humidity in relation to works of art. Museums Journal, 41, 279-283.

Rode, C., Peuhkuri, R., Mortensen, L., Hansen, K., Time, B., Gus-Tavsen, A., Svennberg, K., Arfvidsson, J., Harderup, L., Ojanen, T. \& Ahonnen, J. (2005). Moisture buffering of building materials. Report BYG-DTU R-126, Department of Civil Engineering, DTU, Lyngby, Denmark.

Thomson, G. (1986). The museum environment. Second edition, Oxford: Elsevier Butterworth-Heinemann.

\section{Acknowledgments}

This work was financially supported by: Project POCI-01-0145-FEDER-007457 - CONSTRUCT - Institute of R\&D In Structures and Construction funded by FEDER funds through COMPETE2020 - Programa Operacional Competitividade e Internacionalização (POCI). Cláudia Ferreira would like to thanks to the CONSTRUCT grant UID/ECI/04708/2019.

\section{Authors' Curriculum Vitae}

Cláudia Ferreira, she is graduated in Civil Engineering (FEUP, 2004) and completed a Ph.D. degree in Civil Engineering (FEUP, 2015). She is a Researcher in the Research Unit 
The Influence of Mass Tourism and Hygroscopic Inertia in Relative Humidity Fluctuations of Museums Located in Historical Buildings

Cláudia Ferreira; Vasco Peixoto de Freitas \& João Delgado

CONSTRUCT - Institute of R\&D in Structures and Construction of FEUP, where she develops research about the importance of hygroscopic inertia in museums.

Contact: cmiranda@fe.up.pt

Vasco P. de Freitas, he is Full Professor, since 2001, at the Department of Civil Engineering, Faculty of Engineering, University of Porto. Director of the Building Physics Laboratory, since 1991, at the Faculty of Engineering, University of Porto. Author of more than 350 publications: Books, Chapters of Books, Edition of Books and Conference Proceedings, Papers in International Journals in the area of building physics and building Pathology.

Contact: vpfreita@fe.up.pt

João M.P.Q. Delgado, he is graduated in Chemical Engineering (FEUP, 1995) and completed a Ph.D. degree in Chemical Engineering-Transport Phenomena (FEUP, 2002). He is a Researcher in Civil Engineering at FEUP. Delgado has more than 140 papers published in international journals, 11 international books, 30 book chapters in international books, and more than 130 papers in international conferences. He was invited editor of 15 international books, 23 special issues in international journals, and invited speaker of 4 lectures. He is editor-in-chief of Journal of Building Pathology and Rehabilitation and the Book Series: Building Pathology and Rehabilitation, both by Springer-Verlag; Lead Guest Editor of annual Special Issue: Advances in Building Technologies and Construction Materials of AMSE; and co-chairman of International Conference on Diffusion in Solids and Liquids (DSL).

Contact: jdelgado@fe.up.pt

Article received on 22/02/2019 and accepted on $14 / 07 / 2020$
Creative Commons Attribution License I This is an open-access article distributed under the terms of the Creative Commons Attribution License (СC BY). The use, distribution or reproduction in other forums is permitted, provided the original author(s) and the copyright owner(s) are credited and that the original publication in this journal is cited, in accordance with accepted academic practice. No use, distribution or reproduction is permitted which does not comply with these terms. 